\title{
De dónde serán: Un enfoque de investigación video-a/r/tográfico en un ejercicio de correspondencias ${ }^{1}$
}

Miguel Tejada Sánchez - Universidad del Valle, Cali, Colombia

0000-0002-2195-5557

Recepción: 23.09.2021 | Aceptado: 09.10.2021

Correspondencia a través de ORCID: Miguel Tejada Sánchez

0000-0002-2195-5557

Citar: Tejada Sánchez, M (2021). De dónde serán: Un enfoque de Investigación video-a/r/tográfico en un ejercicio de correspondencias. REIDOCREA, 10(29), 1-20.

Área o categoría del conocimiento: artes y educación

Resumen: En este artículo reflexiono sobre la producción de un conjunto de video correspondencias que hacen parte de un proyecto de tesis doctoral en Artes y Educación. Se propone que este ejercicio de conversación, como el gesto coser y suturar lo desgarrado, encuentre un lugar en los enfoques metodológicos basados en las artes, concretamente en las experiencias en a/r/tografía, una metodología en la que se conjugan los intereses artísticos con problemas específicos de investigación, en este caso con las posibles formas de abordar en contextos educativos el tema del conflicto armado colombiano.

Palabra clave: video-correspondencias

De dónde serán: an a/r/tographic research aproach in a video correspondence work

Abstract: In this paper I refer to the production of a series of video correspondences produced as part of a doctoral thesis in Arts and Education. I suggest that this conversation exercise, like the gesture of sewing or suturing a wound, could articulates with arts based research methods, specifically with $\mathrm{a} / \mathrm{r} /$ tographic works, a practice in which artistic interests merge with specific research problems, in this case with the possible ways of considering in educational contexts the Colombian armed conflict.

Keyword: video-correspondence

\section{Introducción}

\section{La obra de arte, la tesis, la obra de arte}

La pregunta central de mi investigación doctoral en artes y educación se enfoca en la posibilidad de abordar en contextos educativos el tema del conflicto armado colombiano $^{2}$, en este caso a través de experiencias artísticas. El problema de la enseñanza y el aprendizaje del conflicto armado colombiano se enmarca dentro de un campo de estudios en ciencias sociales y humanas conocido como Problemas Socialmente Relevantes (Ramos, 2017). También se habla de Problemas socialmente

\footnotetext{
${ }^{1}$ Este artículo es la versión ajustada y ampliada de una ponencia presentada en el VIII Encuentro de investigadores de cine del XI Festival Internacional de Cine de Cali, 2019.

2 El conflicto armado colombiano al que aludo comienza con el período conocido como la Violencia, que va desde 1925 a 1955 (Molano, 2015). Lo que ocurre en estos 30 años tiene repercusiones duraderas y vigentes: las pugnas por el poder (tierra, estado, religión) se han actualizado conservando los elementos constitutivos. La agudización del narcotráfico, a saber, las alianzas con mafias estatales, con guerrillas de izquierda y paramilitares de derecha, es quizás el fenómeno más complejo que resulta de casi 100 años de conflicto armado. Al margen de todas las iniciativas para acabar con los enfrentamientos armados, el problema del narcotráfico ha sido tratado con desidia, con incompetencia, cuando no ha sido simplemente asumido con un cinismo que comparten gobernantes, mercenarios, subversivos, policías y militares.
} 
vivos $^{3}$ o de temas polémicos, en el caso de la tradición anglosajona (Santiesteban, 2019). Pero a un lado de la discusión que existe en Colombia sobre la presencia o la ausencia de estos temas polémicos y relevantes en los currículos escolares, es clave reconocer que el interés en trabajar a partir de asuntos relevantes y proponer estrategias didácticas novedosas para las ciencias sociales, tiene repercusiones favorables en la educación artística y en el diseño de experiencias estéticas enfocadas en el abordaje de temas complejos. En mi caso, he considerado importante explorar las nociones de experiencia artística, educación artística y formación estética ${ }^{4}$ para pensar en acercamientos al tema del conflicto armado colombiano. Las video correspondencias de las que hablaré, que en algún momento juzgué como obras paralelas a la investigación doctoral $^{5}$, surgen de la necesidad de propiciar una relación sensible con artistas, docentes y estudiantes. Haber dicho en algún momento que esta era una obra paralela o anexa a la tesis doctoral es algo que puedo entender hoy como el resultado de un prejuicio sobre la investigación en artes: que sea común pensar que el artistainvestigador produce sus obras por un lado y por otro le rinde cuentas a la academia, cumpliendo con los formatos y los rituales ya conocidos. Y, sobre todo, sometiendo la narración del hacer artístico a un estilo académico en el que se exige exactitud en la comunicación y se rechazan los modos literarios (Marín-Viadel y Roldán, 2019). Esta idea cambia cuando el trabajo de investigación y la obra artística se articulan en enfoques metodológicos donde las artes son reconocidas como prácticas que permiten hacer investigación y divulgar los resultados a través de formas que bien pueden ser obras de arte culminadas o procesos artísticos. Así, tomé como referencia algunos proyectos cercanos y familiares que han seguido una línea de trabajo que "saca" a los artistas y a sus obras de los museos y los espacios culturales hegemónicos para llevarlos a otros contextos, sobre todo a escuelas públicas y barrios populares ${ }^{6}$. Me pareció importante preguntarme por los artistas, por sus ideas sobre estos procesos, por la relación que estos movimientos tienen con su vocación y sus perspectivas laborales y profesionales, por sus lecturas sobre el contexto social de guerra, precariedad, desigualdad, y, en fin, por las posibilidades de ofrecer sus saberes y sus sensibilidades a otros públicos. A partir de estas inquietudes se dio una conversación

\footnotetext{
${ }^{3}$ En francés questions socialement vives, como lo propusieron Legardez y Simonneaux en 1996 (Jiménez y Felices de la Fuente, 2018)
}

\begin{abstract}
${ }^{4}$ Así se refería a la formación estética Jesús Martín-Barbero (2010): "La formación estética consiste, nada más y nada menos, que en el desarrollo del sentir; esto es, de los sentidos: del ver, el oír, el gustar, el oler, el tocar o el danzar. Se trata de eso que en alguna medida hace parte de la formación que se da en el kínder mediante el juego con figuras, sonidos, colores, volúmenes, tejidos, maderas o metales. Pero que cuando se sale del kínder parecería no tener ya nada que ver con la educación, pues al crecer el niño, la educación debe volverse seria -y serial- rompiendo a la vez con el juego y con el sentir. Incluso la lectura y la escritura son convertidas en mero instrumento de 'tareas escolares' impidiendo que los alumnos jueguen con ellas, las usen expresivamente; pues la expresividad tiene que ver con el sentir, que está reñido con el pensar. Así como la imaginación sigue estando escolarmente situada en el lóbulo opuesto al de la razón. El artículo de Jesús Martín-Barbero se puede consultar en este enlace: http://maritzaldelar.com/comunic-arte/jesus-martin-barbero/
\end{abstract}

\footnotetext{
${ }^{5}$ En esta dirección electrónica se pueden ver algunas de las video correspondencias: https://www.mtejadasanchez.com/de donde seran
}

\footnotetext{
${ }^{6}$ Menciono, por ejemplo, el proyecto Museo + Escuela, liderado por el equipo de Educación del Museo La Tertulia, en Cali, desde el año 2016.
} 
esporádica, irregular, (a veces tímida, a veces intensa) con un grupo de artistas en la ciudad de Cali.

\section{Hipótesis}

Los procesos a/r/tográficos, en este caso las video-correspondencias, permiten generar acercamientos e intercambios sensibles, poéticos, entre quien investiga y las personas que hacen parte del contexto de la investigación. Estas relaciones y estos diálogos, que exceden las formalidades y las delimitaciones de los enfoques de indagación tradicionales de las ciencias sociales, nutren la práctica investigativa y artística y propician en los futuros investigadores el deseo de imprimir en sus memorias y en sus informes aspectos esenciales de su sensibilidad: las impresiones respecto al encuentro con otras personas, las búsquedas estéticas que se corresponden con su cotidianidad y con sus deseos, y la comprensión que tienen sobre su rol en la investigación.

\section{Método}

Este ir y venir se titularía "de dónde serán", como reza el coro de la canción "Son de la loma", de la agrupación cubana Trío Matamoros (1923): de dónde son los cantantes, de dónde serán. Esta forma ambivalente del verbo ser, proyectada hacia el futuro y hacia el pasado, y sometida a una inquietud por el lugar de origen y por el lugar de destino (de dónde vienes, a dónde vas) la consigné en un escrito espontáneo (en modo cuaderno de campo) que realicé en dos momentos, antes y después de visitar al artista caleño Juan Guillermo Tamayo en su taller, iniciando el año 2019. Comenzó como una carta que toma la forma de un retrato escrito inspirado en las palabras de Tamayo y en sus impresiones sobre el presente, en su humor, en su sensibilidad. Es un ejercicio de escritura personal basado en un nivel previo de cercanía y de familiaridad, y la enunciación con la que se dan las primeras puntadas es un heme aquí. Un punto de referencia. Este heme aquí reclama un primer gesto de reciprocidad, un dónde estás, y desde allí se perfilan los primeros trazos de un ejercicio de complicidad cuyo horizonte es la pregunta (compartida) por el quién soy como investigador, como artista, como docente, como espectador o víctima de la guerra. Con Tamayo y con los otros artistas he intercambiado imágenes del tiempo vivido en un sentido estético cotidiano (qué nos llama la atención, qué nos apasiona, qué nos aterra, qué nos desola); hemos cruzado voces, lecturas, titubeos, y hemos jugado a componer, a superponer planos y frases para mantener una reciprocidad a pesar de lo extraño que a veces nos resulta hablarnos tanto o contarnos tanto. Con la artista colombiana Carolina Charry, por ejemplo, este diálogo comenzó cuando me mudé a la ciudad de Granada, en España, para realizar una estancia doctoral de un año. Poco antes de viajar yo había visto la exhibición de un trabajo de Charry en el Museo La Tertulia ${ }^{7}$, en Cali. Quedé impresionado con la complejidad de aquella obra, con los detalles, con las sutilezas, y sobre todo con el efecto misterioso, envolvente, que la artista creó en una sala pequeña. Pensé que ese era el tipo de experiencias artísticas que me gustaría haber presenciado cuando era un chico, un estudiante de secundaria. Con esta reflexión empecé a escribirle notas y comentarios a Carolina, con la intención de tramar algo juntos. Un algo que no tenía la forma de un trabajo ni un proyecto artístico o educativo; el algo era, en esencia, el juego de la urdimbre, de la conspiración inspirados en el misterio artístico. Ella no tardó en disponer un espacio de conversación a través de WhatsApp. Hago énfasis en la noción de espacio porque el gesto mutuo le gana terreno al régimen cotidiano del aprovechamiento del tiempo (hablemos de cosas concretas, productivas, de tareas específicas, de costos y beneficios, de ganarse la vida). El gesto es un acercamiento a

\footnotetext{
7 La obra "Savia solaris" fue presentada en el segundo semestre de 2018 en el Museo La Tertulia, en Cali, Colombia.
} 
la vida del otro, un mirar, oír, sentir sin prisa. Un dónde estás que es un cómo estás. Aquello que parece irrelevante por tratarse de un diálogo entre amigos, cobró para mí una importancia mayor cuando contrasté este espacio ganado, esta oportunidad, con la desazón y la falta de ilusiones que solemos sentir los colombianos:

MIGUEL: Hola Caro. Pues aquí estoy. Aquí estoy y no estoy. No sé dónde estoy. En alguna parte estoy seguramente, si el estar es tener un mínimo esquema de percepción que te acompaña a todos lados y a veces se pone turbio y a veces se pone muy fino, muy delgadito, de seda, ese manto, ese halo de percepción que va contigo a todos lados. Por lo demás, bien. Todo el día estoy leyendo cosas aquí y allá, sin ningún rigor, sin ninguna metodología.

CAROLINA: Hola Miguel, tu meditación sobre el estar me ha hecho sonreír. Sí, si no fuera por el cuerpo uno no sabría dónde está. Si uno está confundido, entonces uno le pregunta al cuerpo cuál es la realidad. Estoy escuchando tu mensaje y voy respondiendo a lo que voy escuchando, entonces voy respondiendo así como por pedacitos (2018. Transcripción de un chat, realizada por Carolina Charry).

Por la espontaneidad con la que inició este ejercicio, en aquel primer momento no se advirtieron dos asuntos importantes que se indican en esta reflexión: el primero es la historia de referencias previas de intercambio epistolar entre artistas y entre personas que crean una obra en varios turnos, en varios tiempos, basándose en las reflexiones sobre sus formas de hacer, sobre sus motivaciones, sus antecedentes, sus coordenadas. En 2011, para mencionar un caso, el Centro de Cultura Contemporáneo de Barcelona (2011) presentó en una exposición el proyecto "Todas las cartas", definido como "un formato experimental de comunicación entre directores que no obstante estar situados en territorios alejados geográficamente, están unidos por la voluntad de compartir ideas y reflexiones sobre todo aquello que motiva su trabajo" (Centro de Cultura Contemporáneo de Barcelona, 2011). Un referente inexorable, sin duda, es el proyecto New York Correspondece School, liderado por el artista norteamericano Ray Johson ${ }^{8}$. La posibilidad de intercambiar arte, procesos artísticos, esbozos, bosquejos, notas de taller, no solamente se vuelve una afirmación política contra el establecimiento burgués museístico. Hace algo más entrañable y poético: propicia una búsqueda rizomática del otro, de sus palabras, impresiones, emociones. Hay un sentido dinámico y relacional en estas posibles emociones: son concatenaciones de cosas, son actos creativos (Berardi, 2017) que tejen complicidades, que forman constelaciones de afecto, empatía y deseo. En el caso del campo del video ensayo este intercambio se ha basado en las imágenes que hablan de los autores o por los autores; las imágenes que traducen las impresiones, las preguntas por el entorno que rodea a los artistas y, de cierta manera, la desazón y la emoción que les produce su tiempo, en medio de la abundancia de imágenes y de referentes, como se sabe que ocurre en el devenir de las artes en la modernidad.

El gesto de componer cuadros o viñetas inspirados en la correspondencia se basa, principalmente, en la obra News from home ${ }^{9}$, de Chantal Akerman (1977). La lectura que la cineasta belga hace sobre las cartas que le envía su madre desde Europa suena (aparece) sobre tomas fijas de la ciudad de Nueva York, donde Akerman vivió entre

\footnotetext{
${ }^{8}$ El MACBA (Barcelona) hizo entre noviembre de 2009 y enero de 2010 una exposición sobre el trabajo de Johnson: https://www.macba.cat/es/exposiciones-actividades/exposiciones/ray-johnson
}

\footnotetext{
${ }^{9}$ Fue Carolina Charry quien me sugirió pensar en esta conexión con la obra de Akerman.
} 

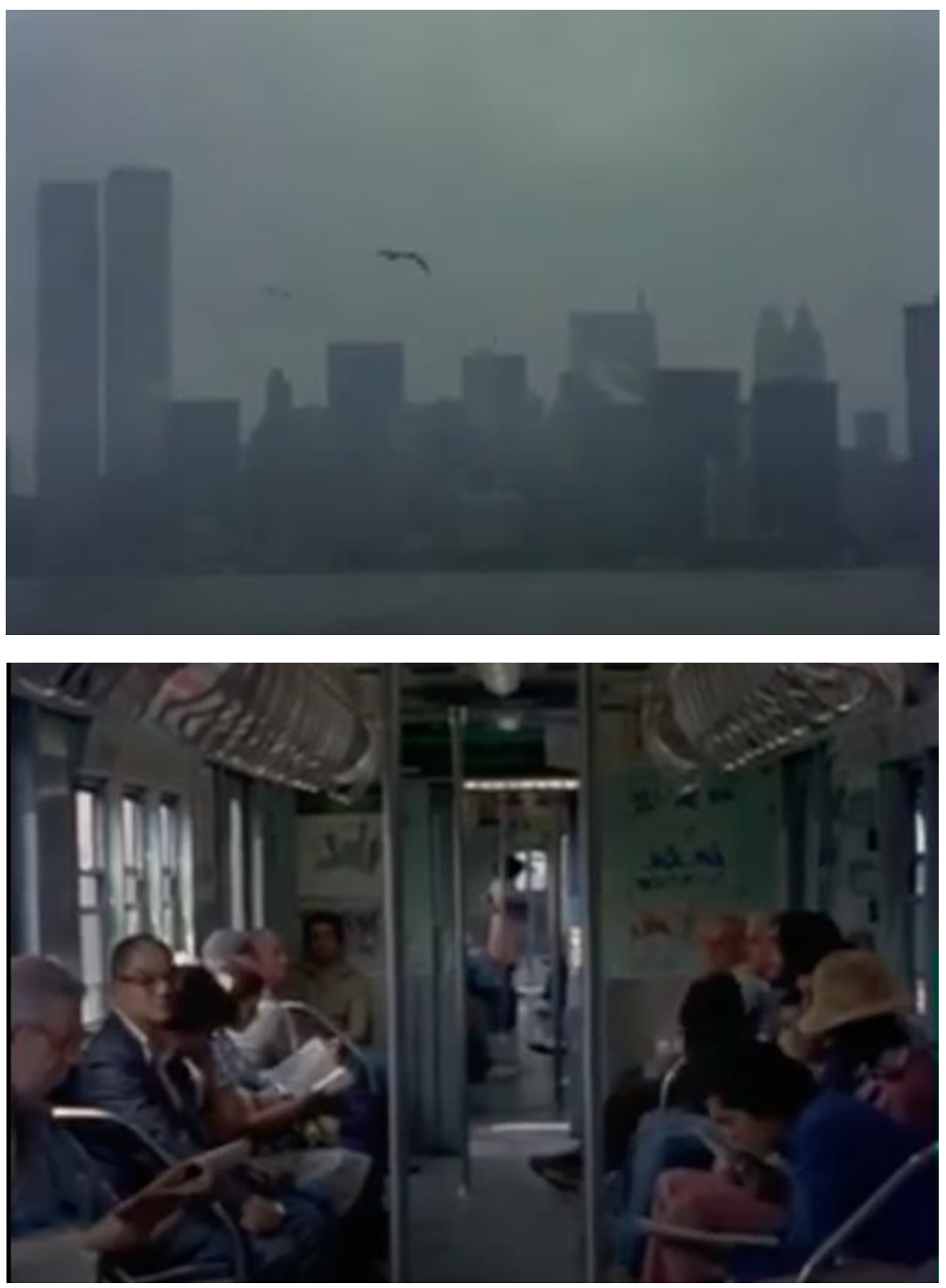

Figuras 1 y 2. Fotogramas de "News from home" (1977), de Chantal Akerman.

La experiencia estética aquí se sale del registro documental en el que las referencias visuales coinciden con los textos y con la información, y lo que suscita en cambio se parece a un juego de composiciones subjetivas en el que cobra relevancia la emoción sentida al escuchar la voz del otro mientras se ve un lugar, una escena, un objeto. Podríamos decir que es un ejercicio en el que se expone una vivencia cotidiana común para reconocerle una potencia poética: las miradas nuestras están teñidas de otras voces, otras percepciones, otras emociones.

El otro aspecto que se considera en esta reflexión, inadvertido cuando este proceso artístico comenzó, fue la posibilidad de que esta obra pudiera pensarse como un referente metodológico para la futura construcción de estrategias e instrumentos artísticos y educativos enfocados en la necesidad de abordar la guerra en Colombia. En este sentido, se puede sugerir que el ejercicio de video cartas o de video 
correspondencias tiene características artísticas que, eventualmente, pueden ser leídas como "estrategias comunicativas y formas de pensamiento" (García-Roldán, 2012) que han encontrado lugar en el ensayo fílmico. Lo importante aquí es que la esencia del ensayo (la tentativa, el esbozo, la especulación) puede proyectarse a otros medios y a otras experiencias, además de lo literario y lo fílmico. Esta forma de ensayar puede pensarse en clave metodológica para espacios educativos y experiencias de aprendizaje, para ampliar las posibilidades de hacer indagaciones y acercamientos a determinados momentos de la realidad social. Tomo como referencia, para imaginar el potencial de estas formas artísticas del ensayo, esta lectura que propone GarcíaRoldán:

\begin{abstract}
"En oposición al género estrictamente documental, el Film-ensayo es considerado como ese espacio donde se puede presentar la verdad sin ambigüedades y una relación con la historia no arbitraria, donde también tiene cabida la contradicción y el juego. El replanteamiento del género del documental y la proliferación de ensayos audiovisuales producidos indistintamente por artistas y cineastas desde el último cuarto de siglo pasado hasta nuestros días, han impulsado el desarrollo de una nueva forma híbrida que en la práctica desdibuja las categorías del cine y del arte, flexibilizando tanto las prácticas de producción como las de exposición o exhibición" (2012, p. 51)
\end{abstract}

La obra adopta entonces la lógica de un intercambio reflexivo; se conjugan las voces y las imágenes enviadas a través del correo electrónico o de una aplicación de mensajería, se comparte un juego de coordenadas (gestos) que forman una espiral cuyo centro es la experiencia de la otra persona; mira dónde estoy, mira cómo miro mi entorno, oye mis dudas, oye mis impresiones, ¿dónde estás?. Este dónde estás es una pregunta relacionada con el lugar que se tiene como artista, y ese lugar en la vida, ese ubicarse o no ubicarse del todo en el oficio y en el contexto cercano, en la vocación y en el propio relato biográfico, nos permite esbozar un primer tejido comprensivo sobre la experiencia artística. En ocasiones, el gesto de la escritura es contestado por los/as artistas con gestos silenciosos que luego alcanzan una resonancia paradójica, como ocurrió con las artistas Angélica Ramírez y Vanessa Sandoval, cuando enviaron de vuelta sus voces leyendo lo que yo había escrito sobre ellas, dándole a mis palabras un segundo aire. A esas voces les superpuse imágenes en video y algunas imágenes fijas que realizaba o encontraba durante mi paso por la ciudad de Granada, entre 2018 y 2019. Me parecía importante darles un tratamiento estético que correspondiera con lo que yo percibía en sus voces (sus estados de ánimo, su fuerza, su interés, sus cuestionamientos) y me permitiera ampliar mi relación con el archivo, con el registro de aquella cotidianidad.

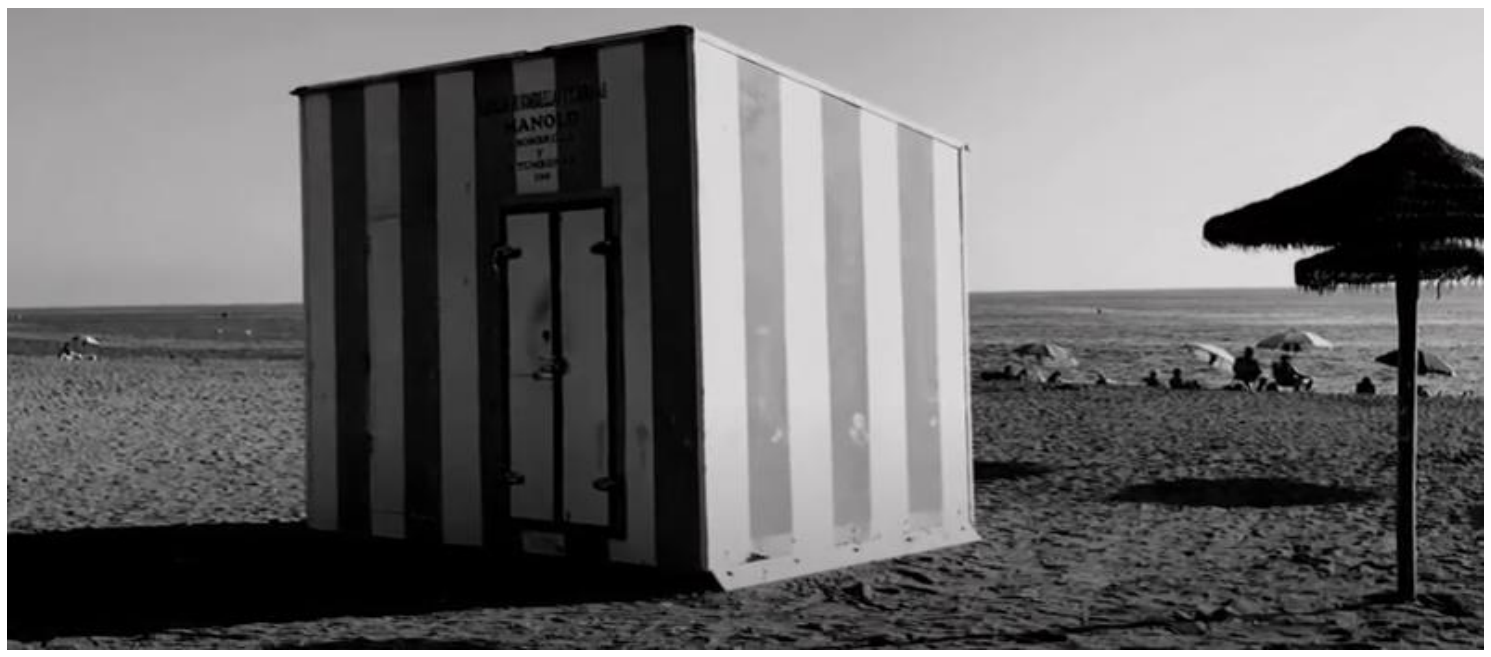

Figura 3. Autor (2019). Fotograma de la serie de dónde serán (Angélica Ramírez) 

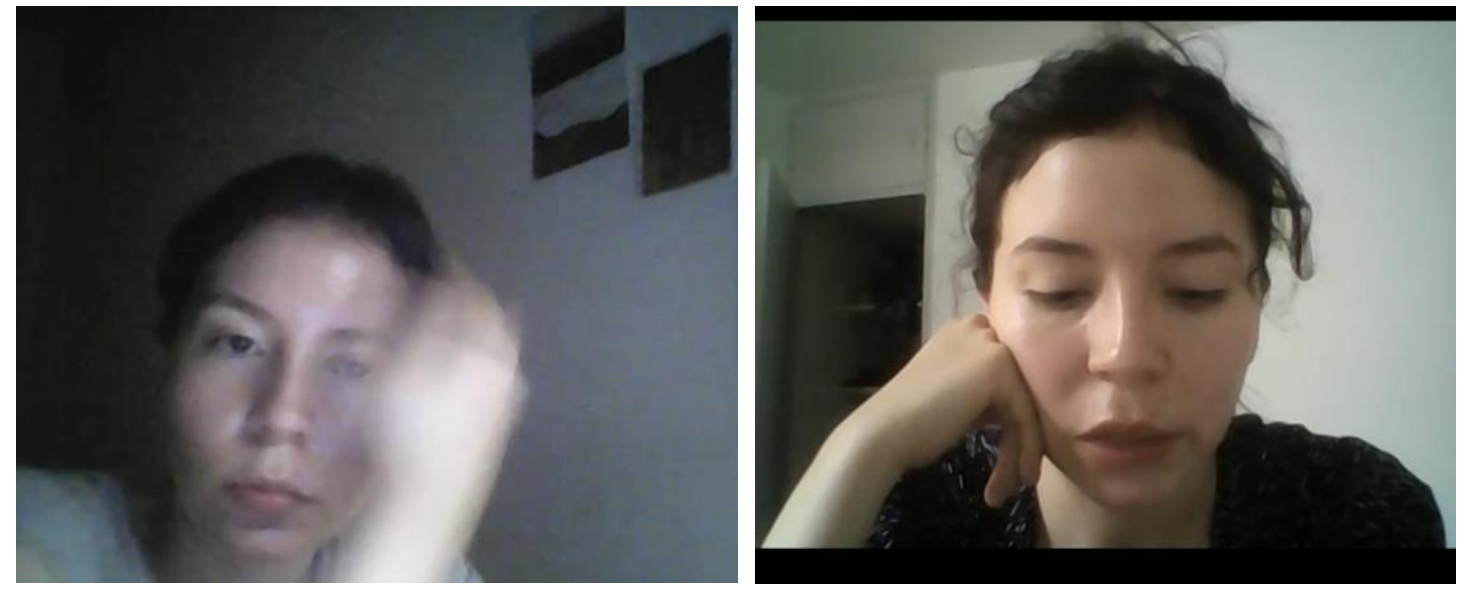

Figuras 4 y 5. Autor (2019). Ensayos de lectura realizados por la artista Vanessa Sandoval.

Resalto el gesto con el que se abre el juego de correspondencias: es como un primer movimiento parecido a un púlsar en un espacio saturado de información. Este envío inicial viene con una invitación a un diálogo cargado de un deseo de ir hacia el otro: te leo, he leído, te he oído, y heme aquí, con esta lectura, con este boceto de impresiones y percepciones sobre el mundo que estamos viviendo. Es un llamado de atención que tiene algo de clamor: necesito hablar contigo, quiero decirte algo, y de provocación: algo sobre ti. Este deseo parte de la impresión de que estoy incompleto, como investigador, como artista, como alguien que busca en la experiencia del otro un consuelo o un complemento. Como todo deseo, es utópico, porque el otro y los otros no son un lugar ni un tiempo alcanzables ni reducibles. Son, a lo mejor, esperanza: con los otros la ilusión vital se extiende, como promesa, como fantasía. Los otros encarnan lo diferente, y esto es el motor del deseo. La esperanza, en este caso, es el delirio de inmortalidad que nos produce la presencia de los otros. La presencia de los otros anula la condena al silencio y al vacío que nos impone la muerte, sobre todo cuando esta muerte es violenta. Dice Joan-Carles Mèlich:

"El ser humano no existe sin esperanza, porque no puede vivir sin el deseo de un mundo diferente, de un nuevo mundo, de un mundo mejor. Una humanidad sin esperanza estaría condenada a ser embaucada por los pragmáticos de turno..." (2012, p.119).

Pienso en lo poco pragmáticos que parecen estos intercambios, si lo que se debe lograr al final es una propuesta de investigación concreta, alejada de los rodeos y de la incertidumbre. Pero este buscarnos, este encontrarnos para hablar en medio de una constante sensación de inestabilidad, fragilidad, precariedad, es la utopía a la que debería uno aspirar si lo que se propone es imaginar formas de (no solo) comprender lo que han producido los conflictos armados, las masacres, las violaciones y proyectar espacios de vida después de este horror. 

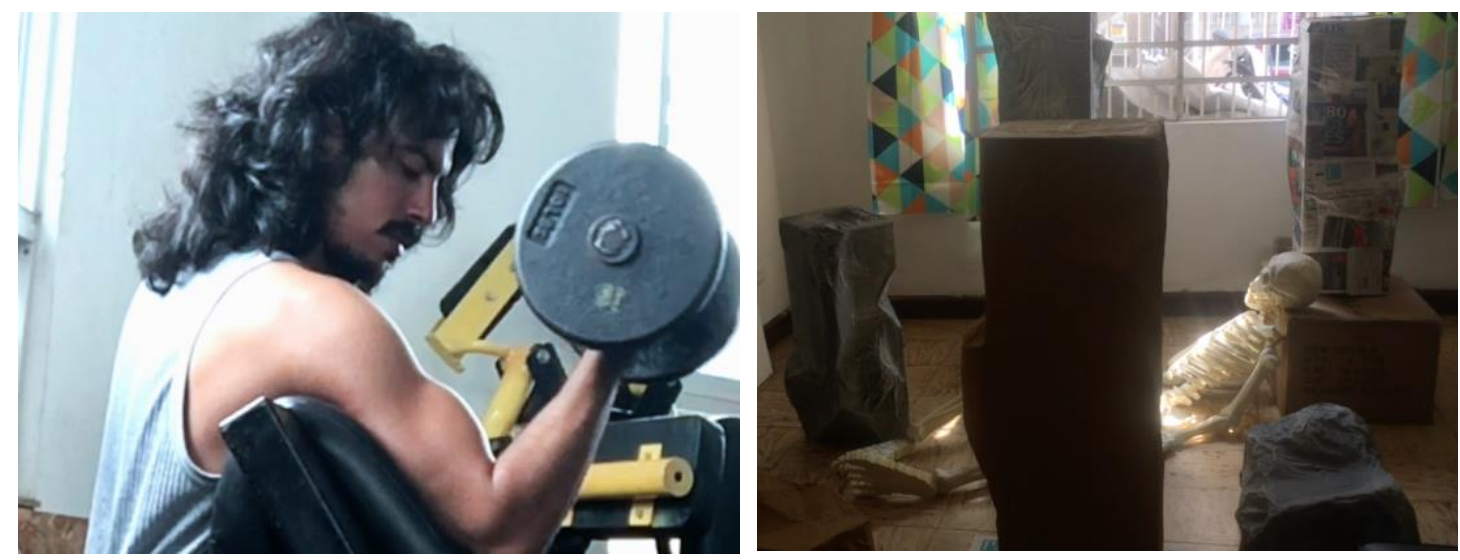

Figuras 6 y 7. (Tejada y Tamayo, 2019). Juan Guillermo Tamayo sugiere el montaje del primer ejercicio de correspondencias vía Whatsapp: “(...)primero va el video del gym loopeado casi como un GIF...y después los esqueletos". Fotogramas de los videos enviados por Tamayo: haciendo pesas en el gym (izquierda) y el esqueleto en el taller de Tamayo (derecha).

Busco entonces que estas video correspondencias puedan ubicarse en un territorio metodológico donde las artes son pensadas como un conjunto de prácticas articulan formas tradicionales de indagación con formas de relacionarse poéticamente con otros interlocutores en un plano personal y afectivo, con sus expectativas, con sus contextos: se trata de la investigación basada en las artes (Arts-based research), que permite un diálogo entre los enfoques tradicionales en investigación social y las formas artísticas, para posibilitar una mejor comprensión de las actividades humanas, como afirma Rita Irwin (2013, p. 107). Así, podemos asumir que las artes no llegan a los estudios sociales como un complemento decorativo o como un elemento que aligera o trivializa la densidad de la producción académica tradicional; tampoco presupone esto una depreciación del rigor de los métodos científicos. Las artes permiten expandir la experiencia cognitiva y la experiencia comunicativa sensible a través de un giro narrativo (Hernández, 2008). Este giro, que se puede pensar como una respuesta estética a los fracasos sociales del siglo XX (tantas guerras, tantos éxodos, tantas hambrunas, tantas bancarrotas), se articula bien con las transformaciones en los modelos de comunicación y las mediaciones ${ }^{10}$ entre las manifestaciones culturales populares y los grandes discursos de la industria y la ciencia. Aquí empezamos a ver cómo se tiene en cuenta al arte como un recurso investigativo en dos sentidos. Por un lado, como una actitud crítica frente a las formas de indagación hegemónicas (que extraen de la realidad sus certezas, a través de procesos limitados en cuanto a su dimensión sensible y comunicable). Por el otro, como una práctica que se nutre de escrituras creativas, literarias, de imágenes, sonidos, en fin, de lo estético como experiencia humana en la que se dan intercambios, pugnas, resistencias y rupturas.

\section{La experiencia estética de la a/r/tografía}

La a/r/tografía es el resultado del trabajo de un grupo de investigación en la Universidad de British Columbia ${ }^{11}$, como una lectura posterior a las definiciones sobre la Investigación Basada en las Artes (IBA) y la Investigación Educativa Basada en las Artes

\footnotetext{
${ }^{10}$ Las mediaciones son las "articulaciones entre prácticas de comunicación y movimientos sociales, a las diferentes temporalidades y la pluralidad de matrices culturales" (Barbero, 1987, p. 203).

11 "La primera noticia documentada del término a/r/tografía indica que fue acuñado por Rita Irwin en las reuniones con el grupo de investigación de su departamento de 'Currículum y Pedagogía' en la Facultad de Educación de la Universidad de la Columbia Británica en Vancouver, Canadá." (Marín-Viadel y Roldán, 2019, pp. 881-895)
} 
(IEBA). El enfoque a/r/tográfico se puede entender como una serie de movimientos (prácticas, reflexiones) que incorporan las artes-el pensamiento y a la acción inherentes a las artes - a las prácticas investigativas, con el fin de fortalecer la comprensión sobre estos procesos de indagación (ha sido, sobre todo, importante en referentes de investigación educativa) y las dinámicas sensibles que se dan en las negociaciones, los debates, los malentendidos y los acuerdos; todo lo que suele ocurrir en contextos donde hay puntos de vista que coexisten en el espacio social (Bourdieu, 1999). Lo peculiar de este enfoque es el interés que se ha puesto en la práctica. De hecho, la a/r/t/ografía procede directamente de la Investigación Basada en la Práctica (la sigla en inglés es PBR: practice based research). Este énfasis en la acción vitaliza los trabajos investigativos y transforma al que investiga y al que participa en la investigación, ya como sujeto de estudio o como actor del entramado social. En este sentido, las prácticas investigativas no se imponen a la vida sino que son la vida misma (Irwin, 2017, p.108). Esto quiere decir que el sentido de la acción implica la maleabilidad de las preguntas, de las expectativas, de las relaciones, y esta cualidad permite entender lo que se investiga como un proceso que cambia sobre la marcha, y es ese cambio lo que genera un sentido inteligible y memorable (un sentido como dirección y como sensibilidad):

Así, mientras que los proyectos a/r/tográficos pueden comenzar con una o más preguntas de investigación, el acto de indagación de vida asume que estas preguntas evolucionarán durante el proyecto. Los a/r/tógrafos logran crear artefactos y textos escritos que describen las comprensiones obtenidas a partir de sus preguntas iniciales; sin embargo, también prestan atención a la evolución de las preguntas generadas durante la investigación misma. (Irwin 2017, 108)

Algo muy importante que anotan Ricardo Marín-Viadel y Joaquín Roldán, investigadores en artes y educación de la Universidad de Granada, en España, es el hecho de que en la Investigación Basada en las Artes (la A/r/tografía parte de esta línea) las preguntas que se formulan no persiguen el mismo propósito reconocible en los enfoques cualitativos y cuantitativos tradicionales:

“(...) el objetivo de la Investigación Basada en Artes no es tanto explicar los acontecimientos educativos o sociales como proponer o sugerir nuevas maneras de verlos o de comprenderlos. En lugar de llegar a conclusiones que cierran un problema lo que se busca es abrir nuevas 'conversaciones' -este va a ser un término identificativo muy recurrente en Investigación Basada en Artes-, más amplias y profundas, sobre el tema investigado. En síntesis, el propósito final es plantear nuevas preguntas más que encontrar respuestas. Esta idea es habitual en arte -a muchos artistas, como al pintor R. Magritte o al cineasta ruso Andrei Tarkovsky se les atribuye haber dicho que el 'arte no da respuestas, sino que hace preguntas"' (2012, p. 886)

He sugerido pues que la serie de dónde serán se considere como una práctica a/r/tográfica por sus características de video-ensayo y por la posibilidad de que sea un antecedente de producción artística que condicionó, en primer lugar, la manera de acercarme a las ideas de algunos artistas para cambiar en mi rumbo la concepción de que el arte podía ser llevado a la escuela como quien lleva un saco de libros o de pinturas y objetos para ser exhibidos. Hablar con artistas me permitió acercarme a las docentes y a los estudiantes con una perspectiva de indagación personal que ya estaba impregnada, prendada (al decir de Katya Mandoki, cuando se refiere a la estesis ${ }^{12}$ ) de las palabras y los gestos que había compartido previamente. ¿Y cómo se manifiesta

12 "En la medida en que se agudiza el prendamiento estésico se agudizan uno o varios sentidos simultáneamente: el oído que se afina más que cualquier otro sentido al prendarnos a la música, la vista al prendarnos a un paisaje o a un rostro hermoso, el olfato ante un aroma delicioso, el gusto ante un sabor, el tacto ante una textura o la combinación de varios..." (2006, p.90) 
este llegar al espacio escolar prendado o inspirado por las ideas artísticas externas? En mi caso, busqué articular estas nociones personales sobre lo artístico con la realidad de esos espacios escolares (recursos materiales, situaciones personales de las docentes y los estudiantes, situación del contexto social, etc). Y la articulación propició, por lo general, que los encuentros artísticos fueran experimentales ${ }^{13}$, que complementaran en algunos casos las obligaciones curriculares y, sobre todo, que permitieran pensar y apropiarse de referencias artísticas, de gestos estéticos y, finalmente, tener espacio y tiempo para considerar aspectos poco conocidos (o a veces totalmente desconocidos) del conflicto armado y social en Colombia. Estos video ensayos o video correspondencias-como antecedentes- también condicionaron la forma de asimilar y elaborar otro proceso artístico con los registros, la documentación y los trabajos que resultaron de los proyectos con tres instituciones educativas de la ciudad de Cali, en Colombia. Fue el artista colombiano Herlyng Ferla quien me ayudó a reconocer que los ejercicios de video correspondencias (en los que él participó) buscaban otra forma de investigar-comprender-sentir a los artistas y a sus contextos, antes de acercarse a los espacios escolares con ideas aprendidas o preconcebidas sobre el arte. Pienso ahora que el resultado de esta forma de acercarme y compartir mi experiencia coincide, en esencia, con lo que se ha definido como experiencia a/r/tográfica, especialmente cuando se trata de presentar los resultados de un proceso de investigación:

"El informe de una investigación a/r/tográfica se distingue porque en él hay más evocaciones que afirmaciones, más resonancias que insonoridades y constantes reverberaciones entre la teoría, la práctica y la poética. No se busca llegar a respuestas cerradas sino a un cuestionamiento continuo de los supuestos desde los que se indaga, y por eso se prefiere hablar de 'comprensiones' en lugar de resultados y de 'provocaciones' mejor que de conclusiones. En cualquier caso, ninguno. de estos conceptos debe entenderse como un criterio excluyente sino más bien como orientaciones o sugerencias sobre la atmósfera propia de la metodología a/r/tográfica". (Marín-Viadel y Roldán, 2019, p. 889)

\section{Juntarse con otros para conspirar: la experiencia artística como referente y problema}

Los ejercicios de video-correspondencias que se exhiben en la obra de dónde serán buscan reunir impresiones, gestos y sugerencias en torno a la experiencia artística y la relación que supone esta experiencia con el tiempo y el lugar donde estamos. Las alusiones a la guerra y a la violencia son a veces metafóricas, murmuradas; a veces ausentes. Busqué en este primer momento ampliar la complejidad de los statements de los artistas y evitar que mis conversaciones con ellos tomaran la forma de entrevistas sobre su obra. Esto nos permitió dedicarnos a un intercambio de tonos y ritmos variados, aludiendo a la cotidianidad y a las reflexiones propias que cada uno tenía sobre la experiencia artística, sobre cómo el contexto de crisis social permea las relaciones con otras personas, con la educación y con el lugar (o el papel) del arte en estos momentos de crisis.

Esta noción de experiencia artística reúne un espectro de reflexiones y vivencias en las que lo estético, como campo problemático, atraviesa de forma conceptual y práctica los límites entre diferentes haceres y teorías artísticas, y nos sitúa en torno a una idea de autonomía y de combatividad; es decir, en un contexto de reflexión y acción donde el

\footnotetext{
${ }^{13}$ La profesora Maritza López de la Roche, en su libro "Formación estética de pies a cabeza" (2021), se refiere así a las Clases Artísticas Experimentales en un colegio de Montpellier: "La 'clase artística experimental' (CAE) abraza lo emocional con lo intelectivo. El trabajo coreográfico, el trabajo musical y el trabajo de escritura, en los términos en los que es diseñado y desarrollado, abren un espacio pedagógico especial, diferente de la clase ordinaria." (2021, p. 166)
} 
arte nos incita a cuestionar, desmontar, invertir prácticas, prescripciones, prohibiciones, abusos y ruindades que son consustanciales a contextos de violencia y precariedad. En esta perspectiva dialogan las nociones de experiencia, ética y testimonio (Mélich, 2006): lo ético como el escenario de encuentro con el otro o con lo otro, con lo extraño; lo ético vehiculado o vertebrado por el hacer artístico, y la experiencia como aquello que nos plantea un camino paradójico e imposible con y hacia los otros; una actitud poética frente a los paradigmas racionales que explican el infortunio con un lenguaje tecnocrático y frío. Es lo que el autor Joan Carles Mèlich sugiere al hablar de lo indisponible, de aquello que no está (lo indisponible o lo que no estará nunca a nuestro alcance: lo absoluto). La experiencia, en un sentido distinto al que traza el experimento (que debe someterse siempre al control), se da en la sorpresa y en la novedad (Mèlich, 2012, p.62); la experiencia supone un camino distinto al de la razón, y este camino apunta hacia la consolidación de un sentido de la existencia en el que se toma una distancia (poética) de la obsesión por lo absoluto, la obsesión por la infinitud. Es una distancia que enriquece la mirada y encauza las energías vitales hacia una contemplación de lo singular, en contraste con la mirada universalista. La distancia poética permite que el chiste vital no se agote en la explicación técnica del mundo:

Seguimos con nuestros paseos. Un día, paseábamos por el malecón y le pregunté:

—Señor Wordsworth, si tiro este alfiler al agua, ¿cree que flotará?

Me contestó:

-Vivimos en un mundo extraño. Tira el alfiler, y ya veremos qué pasa. El alfiler se hundió. (Naipaul, 2004, p.59)

A esta elaboración conceptual se le puede sumar la idea del otro como lo característico y esencial de la experiencia poética y artística. El poema acontece en el encuentro con el otro, dice Byung-Chul Han (2017); la poesía y en general el arte permiten que el otro aparezca e interrumpa nuestro idilio con el espejo y nos arranque de la percepción unívoca de las cosas que nos rodean. Esta es una de las primeras constataciones que se destacan en los inicios de este proyecto de video correspondencias, en unas palabras recibidas por la artista Carolina Charry y luego devueltas como un mensaje en la distancia. Charry describe cómo las palabras oídas alguna vez (mis palabras) encontraron un eco en ella y a su vez le dejaron ver el eco que en otra persona habían encontrado las percepciones suyas sobre la exposición que acababa de realizar en Cali. Sobre estas palabras, se superponen dos planos de video; son planos que hacen correspondencia con dos ideas fundamentales en las palabras de Charry, a saber: la alegría de ver y oír a otros (ver a un grupo de gente bailando en la calle, en Granada, España) y la alegría como concepto problemático en el arte, la alegría del mundo como experiencia, como posibilidad que se puede dar en el intercambio poético (una romería de personas bajo el sol de mayo, junto al malecón del río Tajo, en Lisboa, mientras al fondo, sobre las aguas, se desliza un inmenso crucero repleto de turistas):

"Para mí es una alegría inmensa, y algo muy especial sentir que uno pueda romper una cierta barrera que he sentido toda la vida, y es la barrera del mundo interior, como que el mundo interior esté estallando en llamas, como esa planta, y esté sintiendo tantas cosas y percibiendo la vida y no poder decir eso al otro porque el lenguaje es limitado, el lenguaje verbal (...) y cuando uno habla no logra decirlo todo ni lo puede decir en la forma en que lo está sintiendo...entonces, poder ver que hay un momento en que otro logra sentir eso que yo estaba sintiendo, eso que habita en mí o que habitó en mí es increíble, es como un milagro de la naturaleza..." (Carolina Charry, comunicación personal, 2019) 


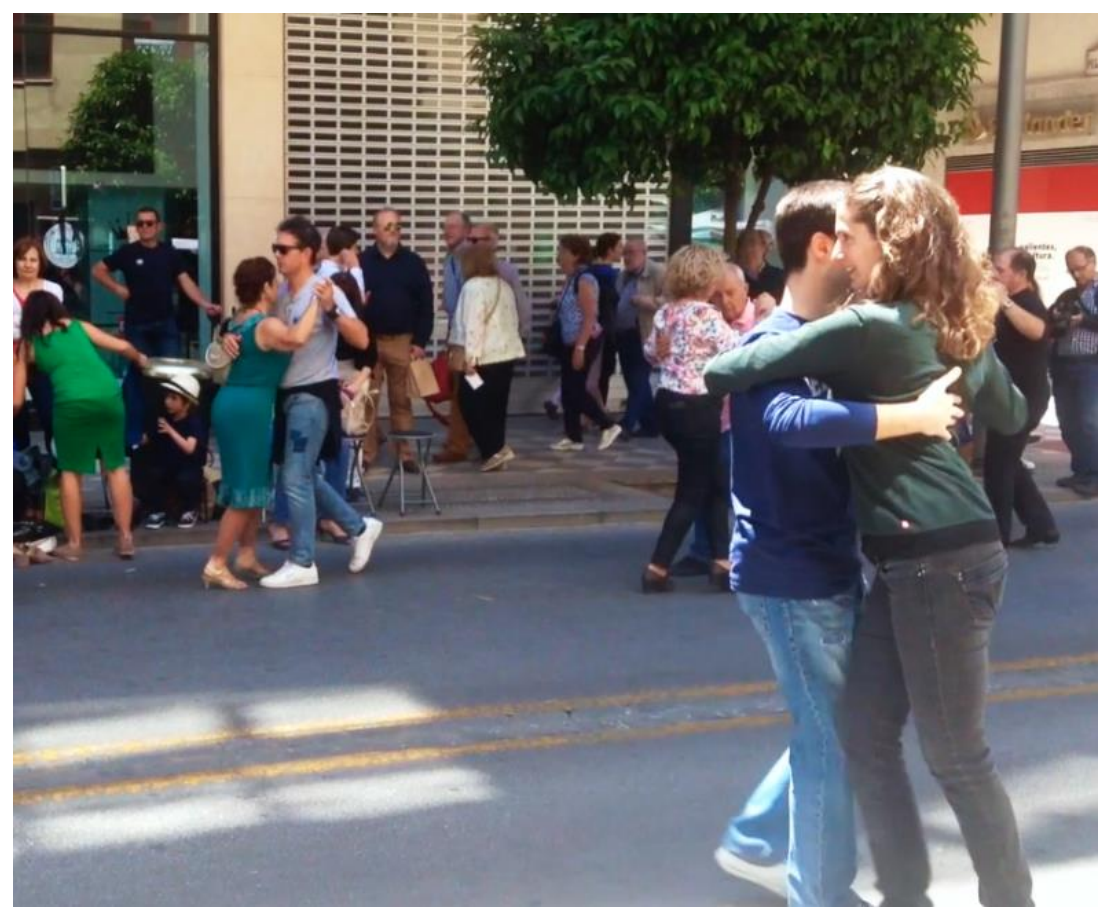

Figura 8. Tejada y Charry. 2019. "De dónde serán (Carolina Charry)." Sobre esta secuencia, las palabras de Charry (en audio extra diegético) esbozan una reflexión acerca de la posibilidad de que la percepción compartida de una obra genere alegría, un sentimiento que suele ser condenado como trivial en un marco de referencias sociales y políticas que tienen un peso trágico, lúgubre o cínico.

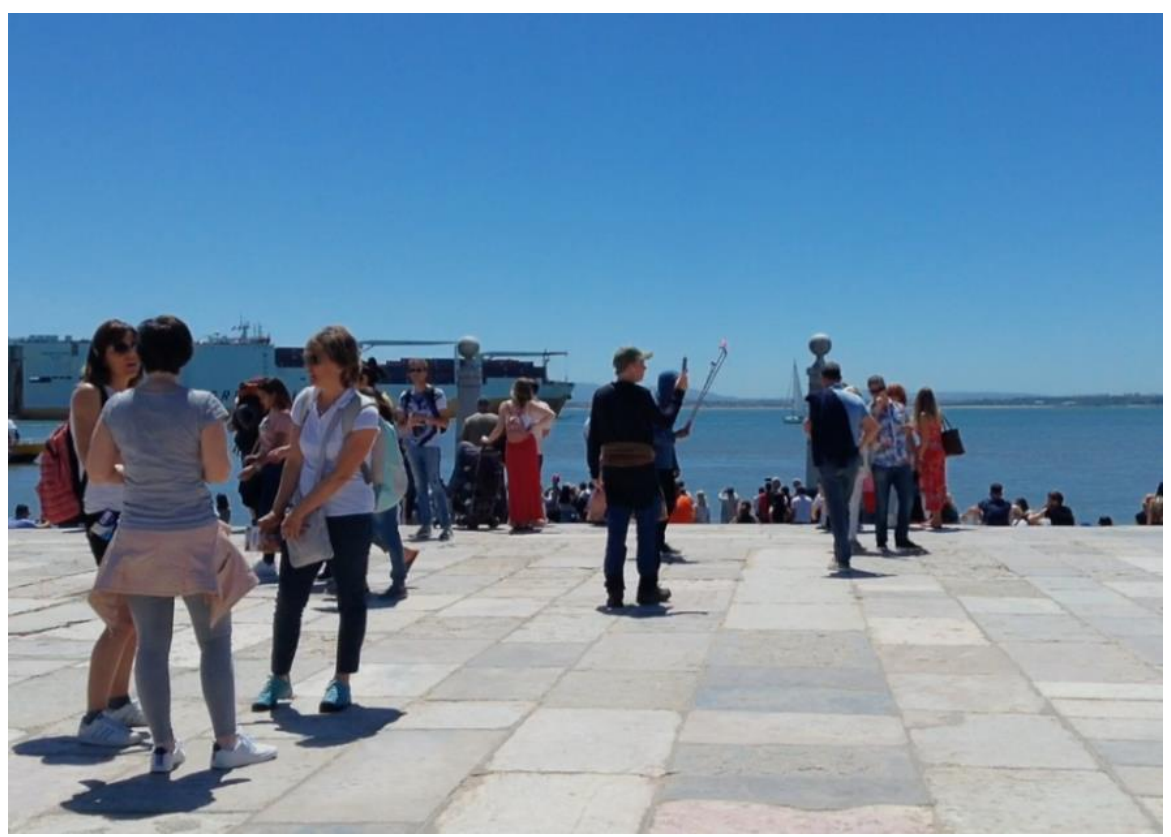

Figura 9. Tejada y Charry. 2019. De dónde serán (Carolina Charry). Sentir que la barrera del mundo interior se rompe, que lo que habita en mí o lo que me habitó alguna vez puede ser percibido por otro.

La relación con lo paradójico ha de entenderse en un sentido literario, tal como se han planteado las correspondencias que componen esta obra, obra que ocurre dentro de otra obra y permite ver gestos poéticos dentro de la investigación doctoral. Es importante, siguiendo la perspectiva de Mèlich, que se entienda que las consecuencias 
del punto de vista literario desde el cual se plantean los intercambios y los encuentros tienen un carácter ético: dar con el otro o dar al otro; darse al otro en un sentido compasivo, en un interés por compartir la vida en lo extraño (lo otro), lo incierto y lo sensible, en fin, todo lo que suele evitarse, cuando no condenarse, en el marco racional instrumental y productivo.

La razón literaria o el punto de vista literario se pueden pensar como una opción metodológica que parte del modo de hacer literario para darle forma a una obra escrita, dicha o cantada y contada a varias voces y con varias manos, precisamente en un tiempo de desasosiego: "(la razón literaria) es la fuente del espíritu que da cuenta de la radical ambigüedad de la vida, de su complejidad, de sus paradojas y de sus contradicciones, un espíritu que posee como única certeza la sabiduría de lo incierto..."(Melich, 2003, p. 38). Aquí encuentro hilos que se conectan la forma como Irwin y Springgay (2008) presentan a la a/r/tografía como un método de investigación que permite desplegar lo artístico y lo textual en un solo cauce; las autoras precisan que lo artístico se puede pensar como el hacer poético, musical, o como otras formas de investigar con el arte, y lo textual, por deducción, equivaldría a la escritura teórica.

\section{Resultados}

Si pensamos que al arte se le ha endilgado la obligación paradójica de no servirle a nada o a nadie, y a la vez de abarcarlo todo, podemos asumir que en ese todo se reúne lo contradictorio de la experiencia humana en la catástrofe del progreso (Garcés, 2017): tenemos los instrumentos para mejorar nuestra propia comprensión del mundo que nos rodea pero el uso de estos instrumentos no nos ha servido para ponerle un freno definitivo a los ciclos de barbarie, porque cada esfera del campo cultural se basta con sus propios exámenes críticos, se limita a sus propios juicios racionales, como islas que producen sus propias alegrías y desdichas hasta que se las traga el mar, sin pena ni gloria: "El problema es que cuando la cultura se reduce a crítica de la cultura, su autonomía queda condenada a la autorreferencialidad: la filosofía como crítica de la filosofía, el arte como crítica de la institución arte, la literatura como crítica de las formas literarias, etc." (Garcés, 2017, pp.42 -43)

Si hablamos de experiencia artística podemos considerar la posibilidad de que nuestros gestos poéticos, nuestras investigaciones a/r/tográficas $y$, en fin, nuestras propuestas estéticas para trabajar en contextos escolares nos sitúen en una crítica permanente a la idea hegemónica de cultura. Sería un cuestionamiento a los nexos entre el campo cultural y el poder; los productos culturales, las prácticas institucionales, las políticas culturales occidentales- paradigma y dogma- que renuevan o dan lugar a formas de obediencia, sumisión y credulidad, formas que se creyeron superadas con el proyecto racional humano, con la ilustración y la modernidad. El cuestionamiento central de esta crítica a la cultura debe señalar, así, que el valor de los proyectos culturales y las mediaciones se podrá juzgar positivamente en tanto que sus posibles efectos de emancipación nos devuelvan "la capacidad de elaborar el sentido y el valor de la experiencia humana desde la afirmación de su libertad y dignidad" (Garces, 2017, p. 43)

Hay que decir que desde América Latina este modelo de los estudios culturales ha sido recibido, adaptado, cuestionado y en no pocas ocasiones re-significado según las alegrías y las desdichas de cada pueblo. Es bien larga la lista de referencias a escuelas, corrientes y tradiciones de pensamiento que han enfocado sus prácticas académicas y sus relaciones con la sociedad en la necesidad de forjar puntos de vista críticos frente al modelo centro europeo y anglosajón. Y así mismo se sabe que la tradición de estudios socioculturales en América Latina es un trabajo que se empieza a consolidar antes de la adopción de los estudios culturales europeos del norte (Crespo y Parra, 2016). Sin 
estar a salvo de polémicas, reveses y frustraciones, se trata en últimas de un proceso de tensiones, distanciamientos y articulaciones que ha significado para las ciencias sociales y humanas, y en los últimos años para las artes, una herencia de resistencias dentro del campo académico y dentro de los espacios de discusión en la sociedad: museos, centros culturales, escuelas, etc. Es cierto que hay modelos hegemónicos, hay corrientes dominantes y hay intereses y recelos dentro de todas estas vertientes que provienen de Estados Unidos y Europa, pero en ese "río revuelto" hay diálogos significativos y procesos de colaboración que se han gestado desde estos lugares hegemónicos para cuestionar sus propias prácticas dominantes y las condiciones políticas que las producen, como el tantas veces mentado y proscrito pensamiento colonialista y el modelo mercantil industrial global.

El arte, en este sentido, sirve o debería servir para entender y sentir por qué adoptamos puntos de vista frente a las cosas del mundo, y se compartiría así una coresponsabilidad afortunada con la filosofía y con las ciencias sociales en general. Aunque no es tan sencillo. La esencia poética del arte le exime de una obligación explicativa y de una servidumbre cultural (Garcés, 2017) en la que se enquistan formas de sumisión, pactos, contratos y transacciones que mantienen intactas las prácticas de opresión contemporáneas. Lo dicho líneas atrás.

Pensar en la experiencia artística en nuestros entornos escolares, en las clases y en los recreos, en las excursiones a la montaña, en las bibliotecas y en los jardines, o en las polvaredas donde no hay proyecto ni esperanza, nos puede revelar una serie de giros inquietantes respecto a la noción de lo artístico como acción sensible y política: el arte como experiencia poética que cuestiona el orden establecido regresa a la institución cultural como el virus que se creía erradicado, como si una horda de poetas regresara otra vez a la República de Platón. Y esta forma peligrosa del arte se puede entender, así, como un medio (y un tiempo) para estar de manera crítica en los problemas del mundo social, con matices y con giros de espontaneidad y rareza que aún no caben en los diseños curriculares de los que fueron expulsados o de los que nunca hicieron parte.

\section{Caminar (juntos) por lo raro}

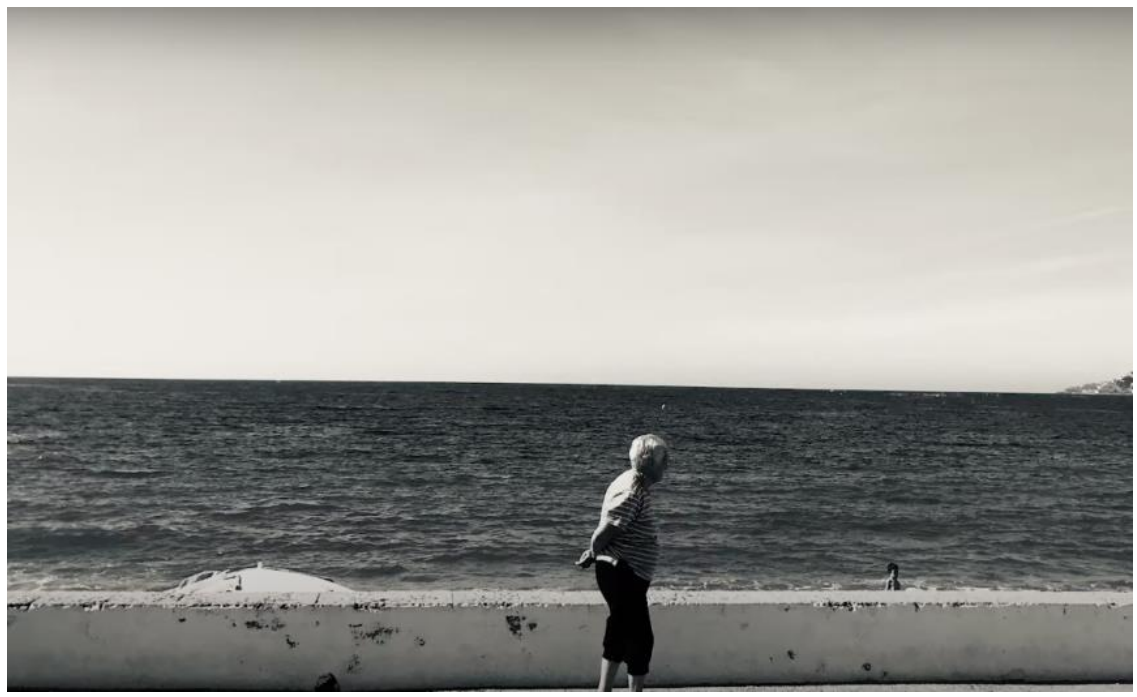

Figura 10. Tejada y Ramírez. 2019. De dónde serán (Angélica Ramírez). La carta-retrato enviada a la artista caleña Angélica Ramírez es leída por ella, y sobre el registro sonoro se superponen imágenes producidas por el investigador. 
El camino del arte es el camino de la extrañeza y de la inquietud, y esto implica mirar los hechos y los acontecimientos desde un punto de vista otro; alejado, en primer lugar, de mi propia experiencia narcisista (Chul Han, 2017), liberado de mis propias credulidades, y alejado, distanciado, del dogma impuesto por el sistema cultural y económico, el dogma de la productividad, que prescinde del misterio y de las incertezas. Pensar en el camino del arte, y en lo que supone encaminarse por la experiencia artística, es pensar en un problema ético que se vive en el plano narrativo y en el plano poético. La noción de experiencia, reitero, se asemeja mucho a la noción de excursión o a la noción de deriva: el que asume este camino, para entender desde una perspectiva no absoluta los problemas de la vida, se desmarca del paradigma tecno-racional y se transforma en este proceso; reconoce el valor del mito y el valor de las incertezas. En un instante de su reflexión sobre la estética del desastre, Byung-Chul Han (2015, p. 63) recuerda las palabras de Maurice Blanchot (1990), su evocación de una escena de infancia: el cielo sin astros, cielo desastrado, le revela al niño la "atopía de lo completamente distinto" (p.63); el exterior vacío, descomunal, lo arranca de sí mismo. Es algo raro de explicar; la contemplación poética del desastre da lugar a una especie de éxtasis místico del que no se habla en los documentos y en los análisis sobre las guerras. Pero aquel estar, aquel sentir, nos sugiere un algo más después del desastre. Es una inquietud que nos incita a pensar en una transformación vital.

Mèlich (2012) habla del incesante proceso de desmitologización, una cruzada fallida, porque la ausencia de mitos implicaría la ausencia de historias-historias que contar, experiencias y vivencias que transmitir - y ese no es el escenario al que me dirijo en este momento. Lo importante aquí es entender que el misterio poético (o artístico) no antagoniza con el pensamiento científico, no es un misterio que oscurece el entendimiento ni la necesidad de conocer más. Al contrario: tienta al sujeto para que atraviese los límites de lo conocido o para que reconozca lo ya conocido y encuentre en aquello nuevas vetas. Es una invitación constante al desconocimiento, a zafarse de las certezas para ver lo otro, lo que a veces no está o lo que a veces no puedo controlar (Camnitzer, 2017).

En un sentido literario, la escritora norteamericana Flannery O'Connor (1989) se refería al misterio de la personalidad como aquello que conforma la esencia de una buena historia. A menudo decimos, con cierto aburrimiento, que la gente hace cosas, y en esa clasificación esquemática de las cosas hay valoraciones técnicas sobre lo relevantes que son esas cosas, para la ciencia y para el arte. Lo que ocurre con estos intercambios que se dan en los video-ensayos es la búsqueda diaria por la estela poética de los gestos cotidianos y por la complejidad que estos gestos adquieren cuando se piensan en contraste con la realidad política y social; hay un ejercicio de contraposiciones y de superposiciones que permite tejer una trama común, un espacio donde lo sensible y lo racional coinciden en el trabajo de comprensión sobre lo que nos ocurre. El misterio de la personalidad del que hablaba Flannery O' Connor se asoma cuando nos fijamos, primero, en esa cotidianidad que parece plana, inmutable para acudir al centro de ese misterio. Más adelante, durante la realización de algunas experiencias artísticas en centros educativos en la ciudad de Cali, en Colombia, pensaríamos en la cotidianidad como un espacio-tiempo en el que se cultivan nuestras formas de ver/oír /sentir los problemas sociales y a las personas que hacen parte de este teatro social: ¿quiénes son los que hacen las guerras? ¿Quiénes son las víctimas? ¿Cómo se transforma y se deforma el mundo (mi mundo, el de otros) cuando hay una guerra?

Claro: no se trata de responderlo todo o decir lo correcto. Es otro decir, otro mirar lo que se busca, lo que se intuye. El problema es que nos han enseñado a cualificar los gestos reflexivos, y por esto, siguiendo a O' Connor, podríamos suponer que una película sobre un hombre que decide tomar una siesta en la acera, sin ninguna razón aparente, es 
menos interesante que una película sobre un hombre que mata a otro hombre. Así, desestimamos la potencia poética que sugiere el acto caprichoso y raro del hombre que, de camino a su oficina, decide desplomarse en la acera: su acción lo pone al nivel de las personas que duermen en la calle, con aquellos desdichados que sueñan con tener una vida normal, una vida de oficinista. Pero lo que busca el oficinista no es descansar ni renunciar a su vida agobiante bajo el régimen de la productividad (Chul Han, 2012); lo que busca es poder soñar otra vez con su propia vida, como si la soñase un habitante de la calle, un extraño, un náufrago, como sugiere la artista Vanessa Sandoval en su serie "El sueño de los náufragos", de 2017, que consistió en dibujar con pétalos, sobre unas telas blancas, siluetas y cuerpos que evocan a aquellas personas que duermen en la calle.
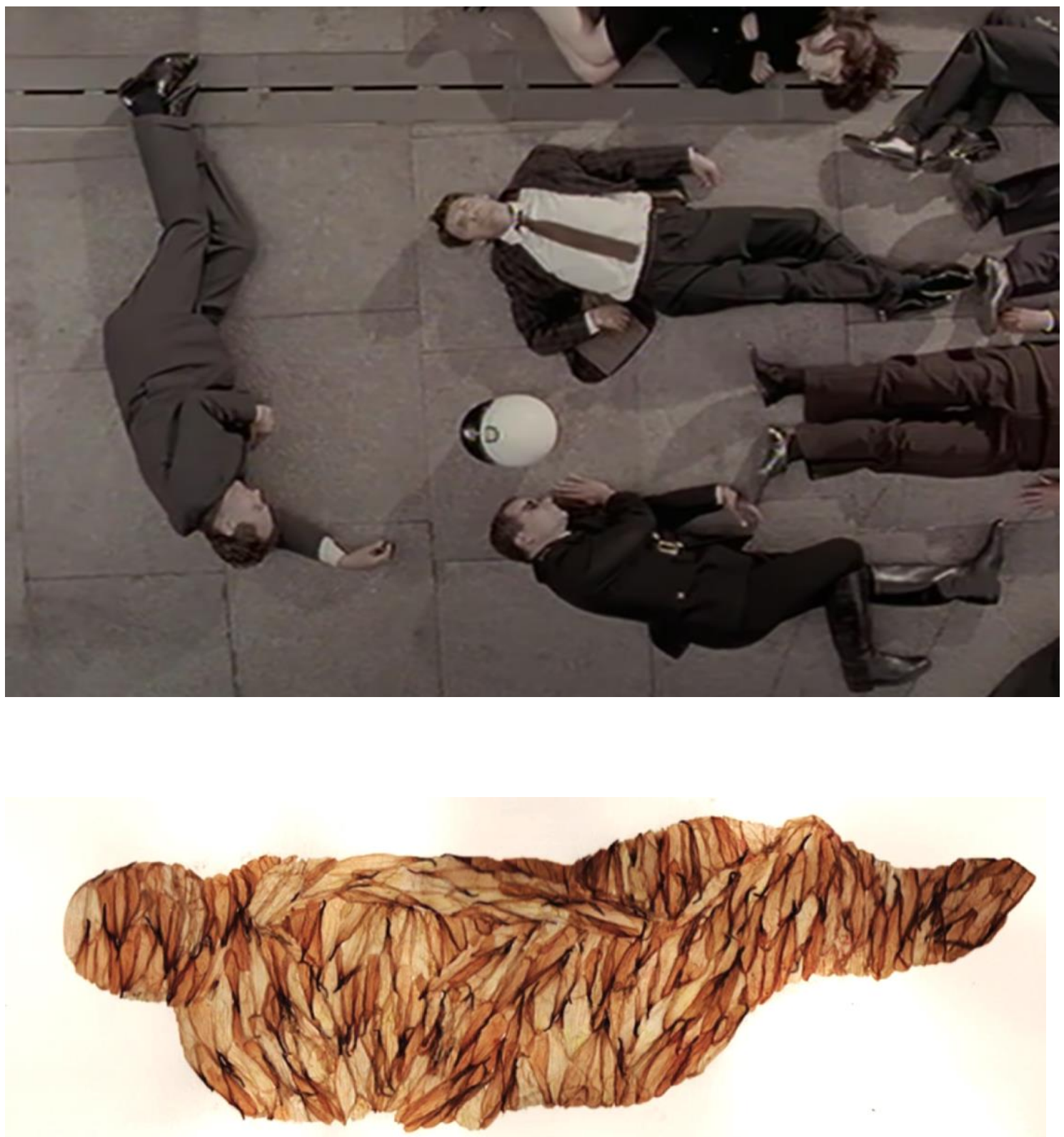

Figuras 11 y 12. Foto ensayo compuesto por dos citas visuales (arriba: fotograma del video-clip "Just" de Radiohead, 1995. Abajo: fotografía de la serie "El sueño de los náufragos”, de Vanessa Sandoval, 2017). 
El arte no se limita a explicar por qué ocurren las cosas y por qué las personas se comportan de ciertas maneras según perfiles psicológicos o estudios socioeconómicos; lo que permite el arte es mantener intacto nuestro dilema ético para los otros: quiénes somos entre un tejido social, quién es el otro, qué siente, qué piensa en relación con los hechos del mundo. Este no resolver, que muchas veces se desprecia como un relativismo o una apatía intelectual que derruye el edificio teórico, se concentra en las personas, en acontecimientos concretos y paradójicos, y juega con la posibilidad de reconocer o desconocer lo que parece definido y explicado; no se trata de sentenciar que la gente es así por determinadas razones, se trata de volver a mirar y de volver a oír, volver a preguntarse por qué extrañamos algo o a alguien, o por qué no podemos dejar de pensar en algo o en alguien. Es una pregunta imposible de resolver en una línea analítica; el extrañarme implica un abandonarme a mí mismo para que ocurra lo otro, o para que algo de los otros, los extraños, los ajenos, ocurra en mí. Este ir y venir entre lo que yo entiendo a partir de mi experiencia en el mundo y lo que entienden o hacen los otros, es un tejido de interpretaciones y relaciones (Mélich, 2012), y este tejido es lo que se ha querido experimentar en la realización de la obra artística paralela al trabajo de investigación sobre la relación entre artes, educación y guerra en Colombia.
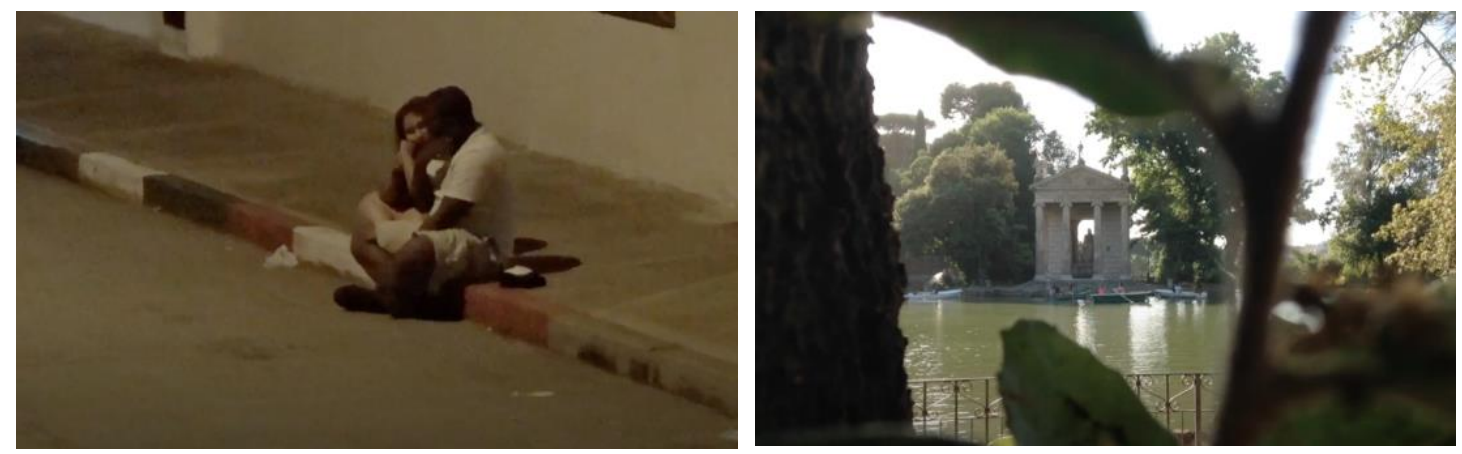

Figuras 13 y 14. Tejada y Samboní. 2019. De dónde serán (Johan Samboní). El artista envía un registro sonoro en el que lee un texto de su autoría y comparte una toma de su calle vista desde su ventana; el investigador escucha el mensaje mientras ve un lago en un parque de Roma.

\section{Discusión}

Se puede decir que el ejercicio planteado en esta obra es una apuesta: se intenta tejer una suerte de hermandad, con sus luces, con sus días felices, y con sus sombras, en un sentido del compartir la vida, en un juego de reciprocidades, de confianzas y de retos; darle un espacio al otro en mi vida, y buscar al otro en sus espacios, en sus pistas diáfanas o ambiguas, en sus derivas. Sin este proceso, sin este juego vital en el que se tejen vivencias, recuerdos y cartografías de nuestras memorias, los actos de reconciliación o los ejercicios de paz imperfecta ${ }^{14}$ no pasarán de ser paréntesis esporádicos y terapias para aliviar padecimientos, nada más. Tampoco se puede pensar en un proceso de investigación sobre la relación entre artes, educación y guerra sin plantearse un oír al otro, sin preguntarse de dónde viene el otro, sin imaginar y soñar al otro. Y como ya se indicó al comienzo de este artículo, el tiempo compartido con los artistas, el tiempo reelaborado en los video-ensayos, ha permitido contar con una trama

\footnotetext{
${ }^{14}$ Dice la doctora Alejandra Toro Calonje que este concepto surgió desde el Instituto de la Paz y los Conflictos de la Universidad de Granada. La paz imperfecta "no es total ni está absolutamente presente en todos los tiempos o espacios sociales, sino que convive con el conflicto y las distintas alternativas que se dan socialmente a éste para regularlo" $(2019$, p. 97)
} 
sensible sobre la que han podido elaborarse otros encuentros con docentes y estudiantes, para abordar con distintas estrategias metodológicas, artísticas, a/rt/ográficas, hechos dolorosos de los que se habla poco, o nada, en nuestras escuelas.

Considerar esta obra como un referente para generar dispositivos artísticos de investigación en el contexto escolar, permite ensayar formas de elaborar memorias de los procesos artísticos, de las experiencias y los resultados del trabajo con docentes y estudiantes; los informes de investigación se pueden concebir, así, como piezas artísticas en las que el trabajo de los otros es tomado, asimilado, tenido en cuenta para ampliar la experiencia estética en un sentido rizomático, poético.

Esto tiene importancia cuando se reconoce en un horizonte donde estos intercambios entre artistas investigadores, docentes y estudiantes generan mapas sensibles y de sentido, mapas de emociones que ayudarán a ampliar la comprensión sobre cómo leemos, cómo sentimos y elaboramos coordenadas del pasado y el presente de violencia y caos social. Lo que se puede revelar en estos ejercicios de correspondencias, tomen la forma de video ensayos, cruces de postales escritas, visuales o sonoras, es la complejidad narrativa y poética que contienen nuestras experiencias vitales, nuestras emociones. Como anota el investigador colombiano Mauricio García Villegas, acudiendo al pensamiento de Spinoza, todo lo que somos "se explica por el tipo de encuentros que tenemos en la vida. Somos el resultado de encuentros con cosas y con personas" (2020, p.154)

La obra de García Villegas es analítica y emocional, como se podría decir de los proyectos de investigación basados en las artes: el interés y la curiosidad del investigador, nutridos por la intuición y por el aprendizaje teórico, dan con hallazgos que contienen características inteligibles y paradójicas, por no decir misteriosas: “¿Qué hay entonces de particular en Colombia? Mi hipótesis es que aquí los sentimientos que alimentan a cada agrupación política han estado plagados de emociones tristes, sobre todo de miedos, odios, venganzas, no-reconocimientos, envidias, etc." (p. 250)

Por supuesto, no basta con decir en clave poética que somos el resultado de encuentros tristes; esta hipótesis admite una ampliación narrativa y analítica, que eventualmente nos permitirá leer, con algo de distancia, cómo esas emociones tristes heredadas se manifestaron en las canciones rurales, en los estallidos sociales, en los programas de televisión, en los noticieros, en la prensa escrita ${ }^{15} \mathrm{y}$, sin duda alguna, en esa particular ambivalencia cotidiana con la que nos sentimos, mal o bien, identificados: que el alborozo de los colombianos (como el de muchos latinoamericanos) se torne con facilidad en una borrasca de pavor y vileza.

\footnotetext{
${ }^{15}$ Como lo indica la investigadora colombiana Alexandra Díaz Marrugo en su tesis doctoral, el lenguaje con el que se ha contado la guerra ha incidido en la comprensión de los hechos, de la identificación de los responsables y las víctimas. En esta entrada de blog se puede leer una versión resumida de sus hallazgos: https://laperorata.wordpress.com/2016/10/10/de-por-que-odiamos-a-las-farc-y-no-tanto-a-losparas/
} 


\section{Referencias}

Berardi, F. (2017). Fenomenología del fin. Sensibilidad y mutación conectiva. Buenos Aires: Caja Negra.

Barbero, J. (1991). De los medios a las mediaciones. $2^{\underline{a}}$ ed. Barcelona: Gustavo Gili.

Bourdieu, P. (2011). Capital cultural, escuela y espacio social. $2^{a}$ ed .México: Siglo XXI.

Bourdieu, P. (1999). La miseria del mundo. Buenos Aires: FCE.

Camnitzer, L. (2017) Ni arte ni educación. Madrid: Matadero Madrid / Catarata.

Broullon-Lozano, M. (2013). Correspondencias fílmicas. La aportación de los cineastas a los estudios sobre el discurso cinematográfico Investigar la Comunicación hoy. Revisión de políticas científicas y aportaciones metodológicas: Simposio Internacional sobre Política Científica en Comunicación Vol. 2, 2013 (Comunicaciones 2), pp. 491 504.

Chul Han, B. (2015). La salvación de lo bello. Barcelona: Herder.

Chul Han, B. (2017). La expulsión de lo distinto. Barcelona: Herder.

Garcés, M. (2017). Nueva ilustración radical. Barcelona: Anagrama.

Crespo, R. \& Parra, D. (2017). ¿Estudios culturales latinoamericanos? Reflexiones a partir de algunas antologías. Latinoamérica. Revista de estudios Latinoamericanos, (64), 13-37.

García, A. (2016). "De por qué odiamos a las Farc (y no tanto a los paras...)"

García, M. (2020). El país de las emociones tristes. Bogotá: Ariel.

García Roldán, Á (2020). El Vídeo-Ensayo En Las Metodologías Artísticas De Investigación. Educación. Comunicación Y Métodos 2 (1), 108-25.

Irwin, R. (2013). La práctica de la a/r/tografía, Revista Educación y Pedagogía, Medellín, U vol. 25, núm. 65, enero-abril, 2013, pp. 106-113.

Jiménez, D. y Felices de la Fuente, M. (2018) Cuestiones socialmente vivas en la formación inicial del profesorado: la infancia refugiada siria como problemática. Revista de Investigación en Didáctica de las Ciencias Sociales. Número 3.

López de la Roche, M Formación estética de pies a cabeza. Cali: Editorial Universidad del Valle.

Mandoki, K. (2006). Estética cotidiana y juegos de la cultura: prosaica I. $2^{a}$ ed. Siglo XXI: México.

Marín-Viadel, R y Roldán, J. . (2019). A/r/Tografía E Investigación Educativa Basada En Artes Visuales En El Panorama De Las Metodologías De Investigación En Educación Artística. Arte, Individuo Y Sociedad 314, pp. 881-895.

Mèlich, J.C. (2011) Filosofía de la finitud. Barcelona: Herder.

Naipaul, V.S. (2004) Miguel Street. Barcelona: Random House. 
O'Connor, Flannery. 1989. Writing Short Stories. En Mystery and Manners. Occasional Prose. Selected and edited by Sally and Robert Fitzgerald. New York.

Ramos, J. (2017). Enseñanza y aprendizaje del conflicto armado en Colombia. Prácticas docentes y conocimiento escolar. Tesis doctoral. Universidad Autónoma de Barcelona.

Santisteban Fernández, A. (2019). La enseñanza de las Ciencias Sociales a partir de problemas sociales o temas controvertidos: estado de la cuestión y resultados de una investigación. El Futuro del Pasado, 10, pp. 57-79.

Springgay, S., Irwin, R., Leggo, C., Gouzouasis, P. (2008). Being with A/r/tography. Sense:Rotterdam / Taipei.

Toro, A. (2017) La presencia de la ausencia: cuerpo y arte en la construcción de paz, la danza como forma de revisibilización de víctimas de desaparición forzada en el conflicto armado colombiano. Tesis doctoral Universidad de Granada. 